\title{
Kjell Skyllstad and Applied Ethnomusicology
}

\section{An Introduction}

This volume of Musicological Annual is dedicated to Prof. Emeritus Dr. Kjell Skyllstad on his $80^{\text {th }}$ birthday and to applied ethnomusicology, the development of which owes him a considerable gratitude.

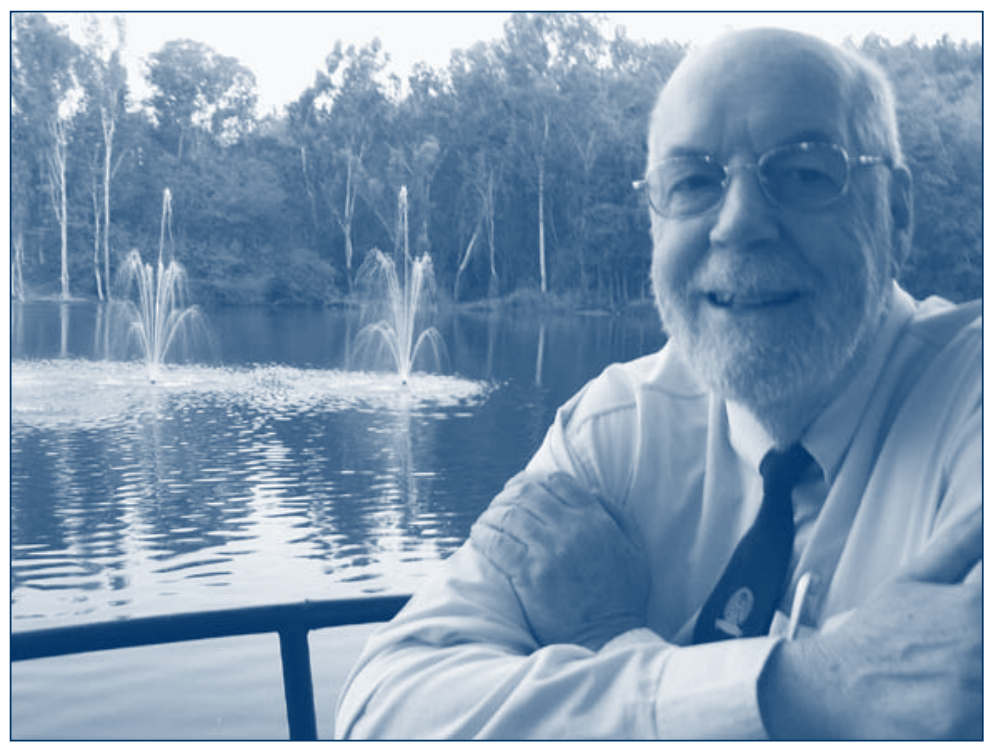

Picture 1. Kjell Skyllstad, Chiangmai (2007)

In the 44-year long history of the Musicological Annual, this is the first of its volumes ever dedicated entirely to the field of ethnomusicology. One of the major reasons for this was certainly the absence of a permanently positioned ethnomusicologist within the Department of Musicology at the University of Ljubljana's Faculty of Arts, which publishes the journal. Lecturers such as Zmaga Kumer, Ph.D. and Igor Cvetko, M.A., both distinguished folk music researchers, were full-time employees of the Institute of Ethnomusicology at the Slovene Academy of Sciences and Arts, which left them with rather limited time to invest into the development of ethnomusicology within the department. This volume coincides with the final part of both internal and external reforms of the study programs, which are expected to considerably increase the presence of ethnomusicology within the department and open new opportunities for upbring- 
ing of new generations of ethnomusicologists. It is also related to two international conferences to be hosted by the department (Approaches to Music Research: Between Practice and Epistemology, May 8-9, 2008, and Historical and Emerging Approaches to Applied Ethnomusicology, July 9-13, 2008, and above all to the celebration of the inspiring colleague and dear friend Kjell Skyllstad, who while approaching the ninth decade of his life increasingly commits himself to new challenges in the world-wide scholarly arena.

Kjell Skyllstad was born in the northernmost city on Earth, the Norwegian Hammerfest, on June 30, 1928. In his own words, "I was born with the rays of the midnight sun reaching my eyes through the windows of the Grand Hotel. A Sami midwife performed traditional birth ritual, probably including giving me a joik, and helped bringing me to life. So, one could say that I was predisposed from birth for engaging in multicultural music activities" (e-mail, April 1, 2008). After completing his studies, he started opening new avenues for musical life in a variety of ways and contexts. In the beginnings, he initiated concerts of early music played on authentic period-related instruments and later promoted experimental performances, bringing together art music and jazz music domains within the International Society for Contemporary Music (ISCM). In the course of his career, he became an expert for music of Norwegian composers such as Edward Grieg, Fartein Valen and Arne Nordheim. Within the realm of Western art music he often immersed himself into research of various innovative themes and approaches, including the relations between music and ideology, focusing on the role of music in totalitarian regimes like Nazi Germany and the Soviet Union.

From the late 1980s he became increasingly aware of the potential of music in fostering intercultural understanding and while embracing ethnomusicological viewpoints and viewpoints associated with some other scholarly disciplines he started to focus on cultural ecology and peace issues. Norwegian Biographical Lexicon from 2006 worded this as follows: "Throughout his whole career Kjell Skyllstad has been a remarkable initiator and a colorful actor on a series of seemingly unrelated fields, excerting considerable influence on national and international musical arenas."

He earned two master's degrees: in education at the Walla Walla University, USA in 1952 and in musicology at the University of Oslo, Norway in 1960, spending a couple of years in between as a DAAD scholar at the University of Munich, Germany. Except for a three year assignment on a research scholarship from the Norwegian Research Council (from 1972) to the Department of Evaluation Research, connected to the Music Academy in Graz, Austria, he served at the University of Oslo's Department of Music and Theater, at which he earned his Ph.D. degree in musicology, for 34 years - from appointment as Assistant Professor in 1962 until his retirement in 1998.

Influenced by his encounter with the cultural conglomerate in the United States of America, he became an advocate of openness, inclusion and cooperation in his native Norway and instead of assuming the traditional role of a musicologist as observer, he started to demonstrate the advantages of action-oriented scholarship. His research of music as an important counterforce to totalitarianism and regimentation led him to explore the potentials of music as a place of cultural encounters, especially after 
increased immigration mostly from Asia, Africa and Latin America began to be felt in the Norwegian society.

In 1975 he established the Intermusic Center, initially concerned with promoting musical cooperation with Asian countries, which is currently led by him, Prof. Bussakorn Sumrongthong from Thailand and the undersigned (see: www.intermusiccenter.com). Within the period between 1989 and 1992 he served as research director for multicultural music project The Resonant Community for the Norwegian Concert Institute (Rikskonsertene). The report of this highly successful project has been translated into Slovene language and published in Glasbena mladina št. 24/4 (1993-94).

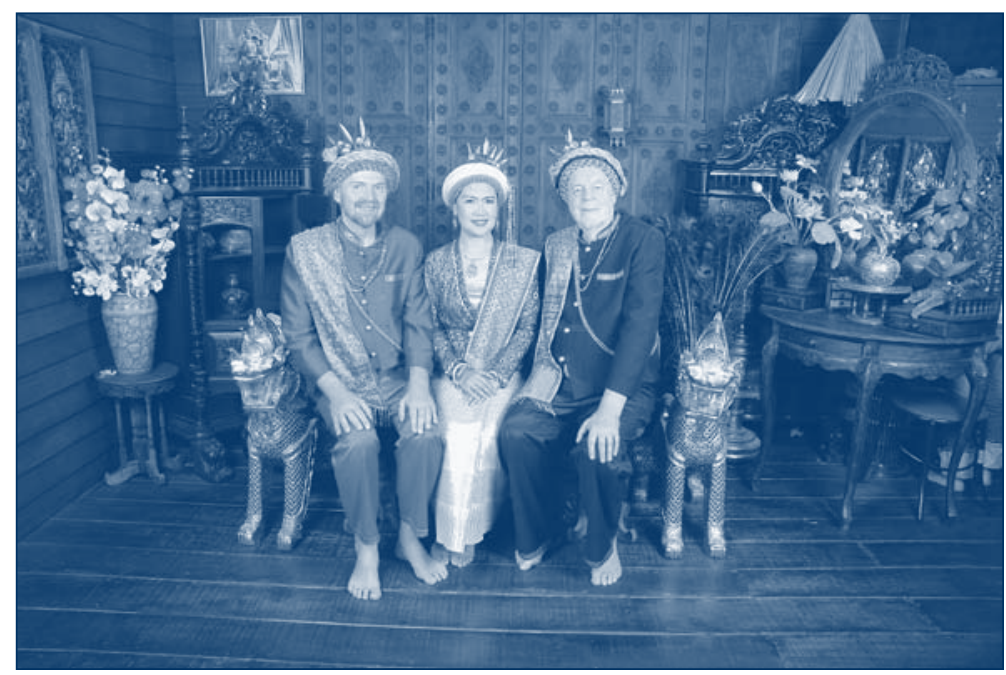

Picture 2. Directors of Intermusic Center, Chiangmai (2007)

Professor Skyllstad's connections with Slovenia go back to the year 1993, when he took part in the Slovene Music Days symposium titled "Music as Provocation". In 1994 and 1996 I was fortunate to cooperate with him at the Department of Music and Theater of the University of Oslo and in several other venues in Norway. We joined forces in bringing to life the project Azra that in the midst of war in Bosnia and Herzegovina linked around music many Norwegians and Bosnian refugees in Norway. We also cooperated at several international scholarly meetings, including the International Society for Music Education conference in Amsterdam in 1996, Music and Minorities conference in Ljubljana in 2000, Invested in Community: Ethnomusicology \& Musical Advocacy in Providence, USA, in 2003, International Peace Research Association conference in Sopron, Hungary, in 2004 and Ethnomusicology and Ethnochoreology in Education: Issues in Applied Scholarship in Ljubljana in 2006. Following Prof. Skyllstad's lectures at the Department of Musicology and at the Music Academy in Ljubljana in 2002, his article "Nordic Symphony - Grieg at the Cross-roads" was published in the Musicological Annual XXXIX/1-2 (2003). In 2007 he provided generous help in 
fostering cooperation between the Bangkok-based Chulalongkorn University and the University of Ljubljana and as a result a group of 11 Thai professors and students came to Slovenia in May 2007. Within the Day of Thai Culture at the Faculty of Arts in Ljubljana and related events they gave concerts, lectures, and workshops, and interacted with carriers of Slovenian cultural expressions. This mutually beneficial intercultural communication will expectedly continue on an annual basis (in February) in the Thai city of Chiangmai.

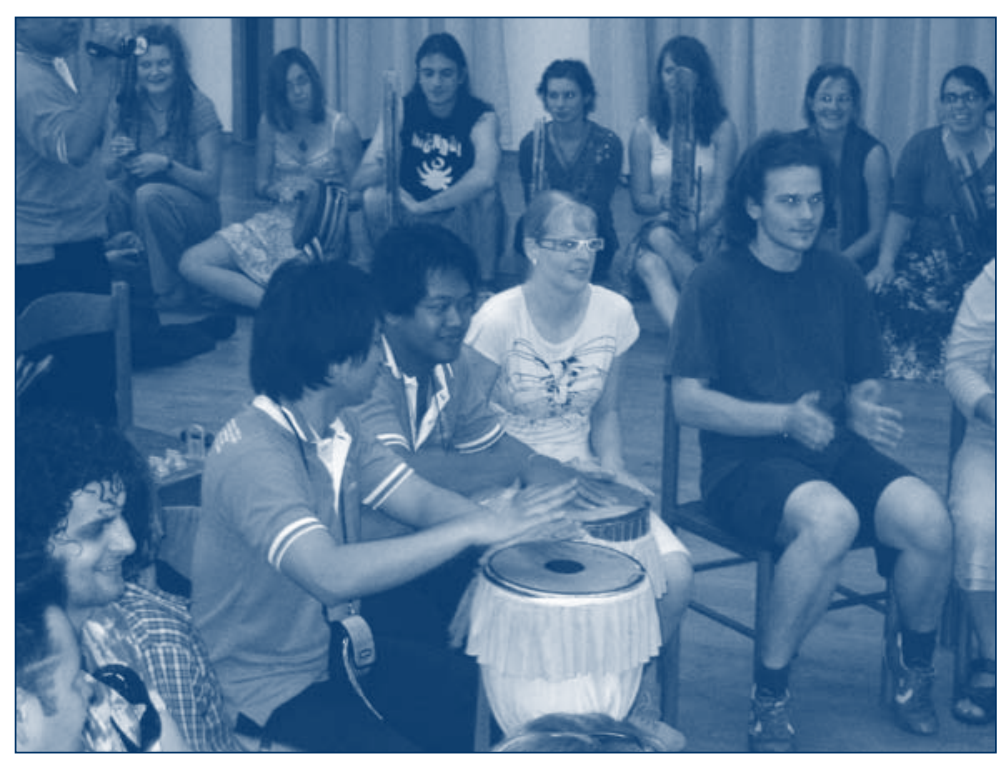

Picture 3. Interaction between Thai and Slovene students, Ljubljana (2007)

All these activities are related to the new program in ethnomusicology at the Department of Musicology and its envisioned Center for Applied Ethnomusicology. The intention to establish a study group focused on applied ethnomusicology has been present among some members of the International Council for Traditional Music (ICTM), which is the world's leading association of ethnomusicologists, for several years. The symposium Ethnomusicology and Ethnochoreology in Education: Issues in Applied Scholarship that took place in September 2006 in Ljubljana served as a major boost in this direction, while the articles for this volume of Musicological Annual derive from the presentations prepared for a double panel The Politics of Applied Ethnomusicology: New Perspectives at the ICTM's 39 ${ }^{\text {th }}$ world conference in Vienna, Austria, in August 2007. Five out of six panel's presenters, each from a different continent - Samuel Araújo (Brazil), Maureen Loughran (USA), Jennifer K. Newsome (Australia), Patricia Opondo (South Africa), Svanibor Pettan (Slovenia), and Tan Sooi Beng (Malaysia) - succeeded in creating articles out of their conference presentations. Due to escalating violence in her native Kenya, Patricia Opondo was unable to join us this time. On behalf of her and 
all the contributors, I attach best expectations to this ethnomusicological Festschrift for Kjell Skyllstad and wish you to enjoy the articles.

Svanibor Pettan

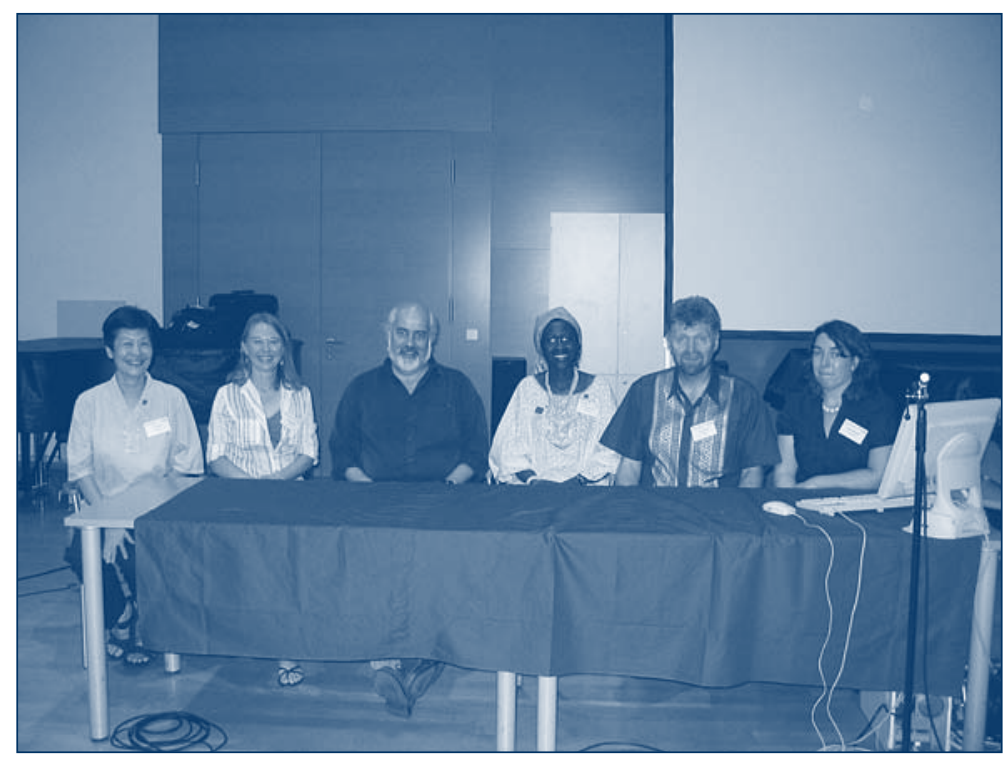

Picture 4. Participants in the panel The Politics of Applied Ethnomusicology: New Perspectives, authors of the articles. From the left: Tan Sooi Beng, Jennifer K. Newsome, Samuel Araújo, Patricia Opondo, Svanibor Pettan and Maureen Loughran, Vienna (2007) 


\section{Kjell Skyllstad in aplikativna etnomuzikologija}

\section{Uvod}

Pričujoči zvezek Muzikološkega zbornika je posvečen emeritiranemu profesorju dr. Kjellu Skyllstadtu ob njegovi osemdesetletnici kakor tudi aplikativni etnomuzikologiji, ki slavljencu dolguje upoštevanja vredno hvaležnost.

V svoji štirinštiridesetletni zgodovini izhajanja je ta zvezek Muzikološkega zbornika prvi, v celoti posvečen etnomuzikološkim vprašanjem. Enega izmed glavnih vzrokov za to je iskati v odsotnosti stalnega učiteljskega mesta za področje etnomuzikologije v okviru Oddelka za muzikologijo Filozofske fakultete Univerze v Ljubljani, ki izdaja zbornik. Predavatelja dr. Zmaga Kumer in mag. Igor Cvetko, pa čeprav ugledna raziskovalca ljudske glasbe, sta bila redno zaposlena na Inštitutu za glasbeno narodopisje SAZU, kar ju je časovno omejevalo pri njunih prizadevanjih za razvoj etnomuzikologije v okviru oddelka. Pričujoči zvezek sovpada z notranjimi in zunanjimi zaključnimi reformami študijskih programov, s katerimi je upati na povečano prisotnost etnomuzikologije znotraj oddelka ter na nove možnosti vzgoje bodočih generacij etnomuzikologov. Prav tako je pričujoča publikacija povezana z dvemi mednarodnimi posvetovanji, ki ju organizira Oddelek za muzikologijo (Pristopi k raziskovanju glasbe: med prakso in spoznavoslovjem, 8.-9. maj 2008, in Zgodovinski in novi pristopi k aplikativni etnomuzikologiji, 9.-13. julij 2008), in predvsem s praznovanjem zanosno vzpodbudnega kolega in dragega prijatelja, Kjella Skyllstada, ki se navkljub nastopajoči deveti dekadi življenja okrepljeno posveča novim izzivom na svetovnem znanstvenem prizorišču.

Kjell Skyllstad se je rodil v najbolj severnem mestu na svetu, v norveškem Hammerfestu, 30. junija 1928. Z njegovimi besedami: »Rodil sem se, med tem ko so žarki polnočnega sonca osvetljevali moje oči skozi okna Grand Hotela. Samijska (laponska) babica, ki mi je pomagala na svet, je opravila tradicionalni rojstni obred, tako da je v samščini zapela tudi joik. Kar pomeni, da sem bil že z rojstvom vnaprej določen za ukvarjanje z multikulturnimi glasbenimi aktivnostmi« (e-mail, 1. aprila 2008). Po zaključku svojega študija je zastavil nova pota glasbenega življenja, in to na različne načine in v različnih povezavah. Najprej je vpeljal koncerte zgodnje glasbe, ki so jo izvajali na prvotnih, obdobjem ustreznih instrumentih, nakar je pospeševal eksperimentalne prireditve, ki so povezovale umetno glasbo z raznimi področji jazza v okviru Mednarodnega združenja za sodobno glasbo (ISCM). V svoji karieri je postal izvedenec za glasbo norveških skladateljev, kot so Edward Grieg, Fartein Valen in Arne Nordheim. Na področju zahodne umetne glasbe se je večkrat podal v raziskovanje različnih novodobnih tem, med drugim tudi odnosov med glasbo in ideologijo, pri čemer se je osredotočal na vlogo glasbe v totalitarnih režimih, kakršna sta bila nacistična Nemčija in Sovjetska zveza.

Od poznih osemdesetih let dalje se je vse bolj zavedal možnosti, ki jih lahko ima glasba pri pospeševanju medkulturnega razumevanja, in se je začel ukvarjati s kulturno 
ekologijo in z mirovnimi vprašanji, v katere je vključil etnomuzikološke poglede kakor tudi stališča, povezana z nekaterimi drugimi znanostmi. V Norveškem biografskem leksikonu iz leta 2006 lahko v tej zvezi med drugim beremo: »V vsej svoji karieri je bil Kjell Skyllstad pobudnik in viden znanstveni delavec na vrsti navidez nepovezanih področij, pri čemer je imel nemajhen vpliv na dogajanje na domačem in mednarodnem glasbenem prizorišču«.

Dosegel je dva magisterija: iz pedagogike na univerzi Walla Walla, v ZDA leta 1952, in iz muzikologije na Univerzi v Oslu 1960. Dve leti je kot štipendist fundacije DAAD deloval na Univerzi v Münchnu. Razen treh let, ki so bila na podlagi štipendije Norveškega raziskovalnega sveta (od 1972) posvečena raziskovalnemu delu na Inštitutu za raziskovanje vrednotenja pri Glasbeni akademiji v Gradcu, je Kjell Skyllstad na Oddelku za glasbo in gledališče Univerze v Oslu, na kateri je dosegel doktorat iz muzikologije, delal 34 let - od izvolitve za docenta leta 1962 do upokojitve 1998.

Pod vtisom srečanja s kulturnim konglomeratom v ZDA je postal pobudnik odprtosti, vključevanja in sodelovanja v svoji domovini Norveški in, namesto da bi si lastil tradicionalno vlogo muzikologa-opazovalca, se je začel zavzemati za prednosti akcijsko usmerjene znanosti. Njegovo raziskovanje glasbe kot pomembne sile proti totalitarnosti in reglementaciji ga je vodilo v odkrivanje potencialov, ki jih lahko ima glasba kot kraj kulturnih srečanj, še zlasti potem ko je bilo na Norveškem čutiti posledice povečane imigracije, posebej iz Azije, Afrike in Latinske Amerike.

Leta 1975 je osnoval Interglasbeni center, ki se je v začetku zavzemal za glasbeno sodelovanje z azijskimi deželami; poleg Kjella Skyllstada center vodita prof. Bussakorn Sumrongthong iz Tajske in podpisani (gl.: www.intermusiccenter.com). Med letoma 1989 in 1992 je bil prof. Skyllstad vodja multikulturnega glasbenega projekta Zvočna skupnost pod okriljem Norveškega koncertnega inštituta (Rikskonsertene). Poročilo o tem zelo uspešnem projektu je bilo prevedeno v slovenščino in leta 1994 objavljeno v Glasbeni mladini, št. 24/4 (1993-94).

Prof. Skyllstadove zveze s Slovenijo segajo nazaj v leto 1993, ko se je udeležil Slovenskih glasbenih dnevov, simpozija pod naslovom »Glasba kot pravokacija». V letih 1994 in 1996 je podpisanemu bilo dano, da sodeluje z njim v okviru Oddelka za glasbo in gledališče Univerze v Oslu ter v različnih krajih na Norveškem. Sredi vojne vihre v Bosni in Hercegovini sva uresničila projekt Azra, ki je ob glasbi združil mnoge Norvežane in bosanske begunce na Norveškem. Razen tega sva organizirala zasedanja ob mednarodnih znanstvenih srečanjih, tako ob posvetovanju Mednarodnega društva za glasbeno vzgojo (ISME) v Amsterdamu leta 1996, konferenco Glasba in manjšine v Ljubljani leta 2000, mednarodni posvet Vlaganje $v$ skupnost ob posredovanju etnomuzikologije in glasbe $\mathrm{v}$ mestu Providence, ZDA, leta 2003 in konferenco Mednarodnega združenja za mirovne raziskave (IPRA) v Sopronu na Madžarskem leta 2004. Prav tako pa je v letu 2002 prof. Skyllstadovim predavanjem na Oddelku za muzikologijo in Glasbeni akademiji v Ljubljani sledila tudi objava njegovega članka »Nordijska simfonija- Grieg na razpotju« v Muzikološkem zborniku XXXIX (2003) 1-2. Leta 2007 je zopet velikodušno pomagal pri vzpostavljanju sodelovanja med univerzo Chulalongkorn v Bangkoku in ljubljansko univerzo, čemur je v maju 2007 sledil obisk enajstih tajskih profesorjev in študentov v Sloveniji. V okviru Dneva tajske kulture na Filozofski fakulteti v Ljubljani 
in spremljevalnih dogodkov so gostje koncertirali, predavali in vodili delavnice ter se z nosilci slovenskega kulturnega izpovedovanja medsebojno oplajali. To obojestransko koristno medkulturno sodelovanje naj bi našlo tudi svoje vsakoletno nadaljevanje februarja v tajskem mestu Chiangmai.

Vse omenjene aktivnosti so povezane z novim študijskim programom etnomuzikologije na Oddelku za muzikologijo in njegovim načrtovanim Centrom za aplikativno etnomuzikologijo. Že več let je bila namera po ustanovitvi študijske skupine, ki bi se posvetila aplikativni etnomuzikologiji, prisotna med nekaterimi člani Mednarodnega sveta za tradicijsko glasbo (ICTM), sicer vodilnega etnomuzikološkega združenja. Simpozij Etnomuzikologija in etnokoreologija v vzgoji in izobraževanju: vprašanja aplikativne znanosti, ki se je odvijal v Ljubljani septembra 2006 (poročilo Mojce Kovačič in Urše Šivic je bilo objavljeno oktobra 2006 v Biltenu ICTM-a), je predstavljal močno vzpodbudo v tej smeri, medtem ko članki pričujočega Muzikološkega zbornika izhajajo iz referatov v okviru dvojne okrogle mize Politika aplikativne etnomuzikologije: nove perspektive ob 39. svetovnem srečanju ICTM-a na Dunaju avgusta 2007. Pet izmed šestih panelistov, vsak z različnih kontinentov - Samuel Araújo (Brazilija), Maureen Loughran (ZDA), Jennifer Newsome (Avstralija), Patricia Opondo (Južna Afrika), Svanibor Pettan (Slovenija) in Tan Sooi Beng (Malezija) - so uspeli oblikovati članke, ki so sloneli na njihovih konferenčnih predstavitvah. Zavoljo povečanega nasilja v njeni domovini Keniji se nam tokrat žal ni mogla pridružiti Patricia Opondo. V njenem imenu in v imenu vseh sodelujočih naklanjam kar najboljša pričakovanja temu slavnostnemu etnomuzikološkemu Zborniku in slavljencu, Kjellu Skyllstadu, vsem pa želim obilo spodbudnega branja.

Svanibor Pettan

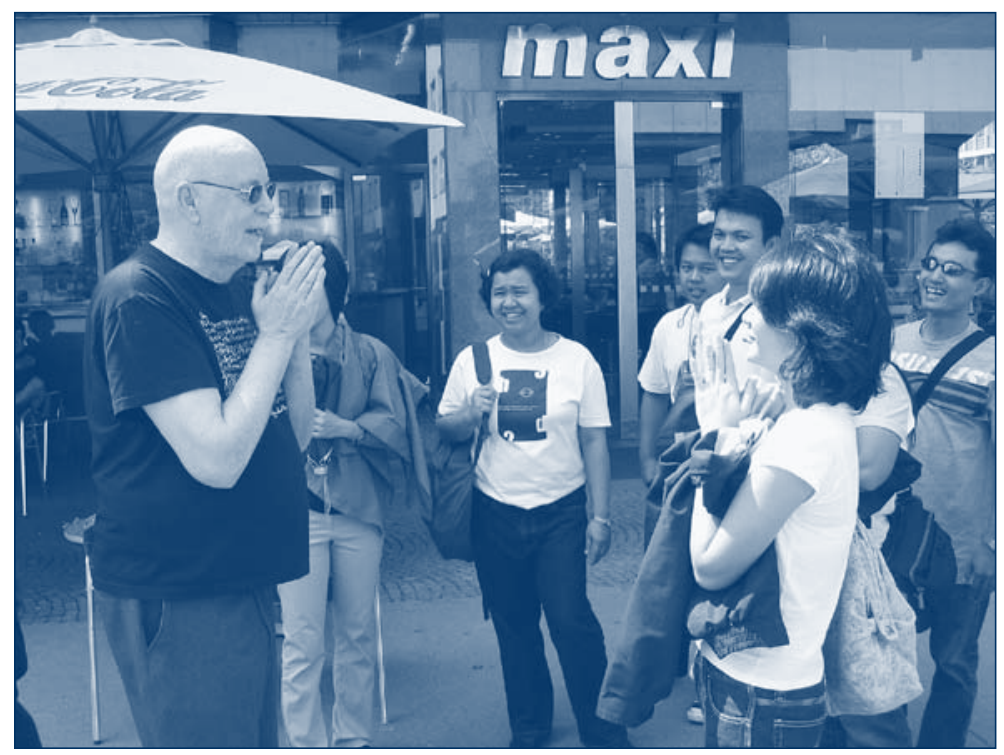

Slika 1: Kjell Skyllstad ob Dnevu tajske kulture, Ljubljana (2007) 